\title{
Hurthle Cell Carcinoma of the Thyroid: A Case Report of 12 Cases
}

\author{
Jung Jun Kim, Ju Yong Kang, Ik Joon Choi, and Myung-Chul Lee ${ }^{D}$ \\ Department of Otorhinolaryngology-Head and Neck Surgery, Korea Cancer Center Hospital, Korea Institute of Radiological and \\ Medical Science, Seoul, Korea
}

갑상선의 휘틀세포암 12 예

김정준 · 강주용 · 최익준 · 이명철

한국원자력의학원 원자력병원 이비인후-두경부외과

\author{
Received August 25, 2020 \\ Revised October 14, 2020 \\ Accepted October 15, 2020 \\ Address for correspondence \\ Myung-Chul Lee, MD, PhD \\ Department of Otorhinolaryngology- \\ Head and Neck Surgery, \\ Korea Cancer Center Hospital, \\ Korea Institute of Radiological \\ and Medical Science, 75 Nowon-ro, \\ Nowon-gu, Seoul 01812, Korea \\ Tel $+82-2-970-2173$ \\ Fax $+82-2-970-2450$ \\ E-mail entdok@gmail.com
}

Hurthle cell carcinoma (HCC) is a relatively rare disease, which comprises about $3 \%$ of differentiated thyroid carcinoma. HCC is considered to have more aggressive clinical behavior compared with other differentiated thyroid carcinoma. However, there has been no consensus about clinical behavior and optimal treatment of HCC because of insufficient reports. Moreover, owing to geographical characteristics, HCC is rarer in Korea than in western countries. Based on 2017 World Health Organization classification, HCC is newly classified as an individual group, not as a subtype of follicular thyroid carcinoma. Therefore, we report data of $12 \mathrm{HCC}$ patients who underwent surgery in our center from January 2000 to May 2020 with a review of the literature. Korean J Otorhinolaryngol-Head Neck Surg 2020;63(12):615-9

Key Words Hurthle cell · Prognosis · Thyroid carcinoma · Thyroidectomy.

\section{서 론}

휘틀세포(Hurthle cell) 종양은 갑상선 종양의 3 10\%를 차 지하는 비교적 희귀한 고분화성 종양으로서, 갑상선의 여포 상 표피(follicular epithelium)에서 기원한 경계가 뚜렷한 다 각형의 세포들로 이루어져 있다. 휘틀세포암(Hurthle cell carcinoma)은 휘틀세포 종양이 의심되는 경우의 $5 \sim 35 \%$ 정도를 차지하는데, 병리 조직 검사상 피막이나 혈관 침습이 있으면 서, $75 \%$ 이상의 휘틀세포로 구성이 되어 있으면 진단할 수 있다(Fig. 1).

휘틀세포암은 발생 빈도가 드물며, 수술 전 세침흡인검사로 양성과 악성의 구별이 불가능하여 1차 수술적 절제 범위를 결정하는 데 어려움이 많다. 또한 완결 절제술과 방사성 요오

This is an Open Access article distributed under the terms of the Creative Commons Attribution Non-Commercial License (https://creativecommons.org/licenses/by-nc/4.0) which permits unrestricted non-commercial use, distribution, and reproduction in any medium, provided the original work is properly cited.
드 치료 등의 추가 치료 방법에 대한 통일된 견해도 명확하지 않은 상황이고, ${ }^{2)}$ 요오드 섭취가 풍부한 우리나라의 지역적 특성상 대부분의 갑상선 암이 유두암이어서 휘틀세포암에 대한 국내의 보고는 거의 없다. ${ }^{3)}$ 이에 저자들은 문헌 고찰과 함께 본원에서 다양한 방법으로 치료한 12예의 휘틀세포암 환자를 보고하고자 한다.

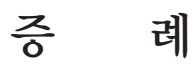

2000년 1월 2020년 4월까지 한국원자력의학원 원자력병 원에서 수술적 치료를 받은 휘틀세포암 12예를 정리하였다. 연령 및 성별, 내원 시 주 증상, 수술 전 세침흡인검사 결과, 수술 방법, 수술 후 방사성 요오드 치료 여부, 재발 여부, 마 지막 추적 관찰 시 상태를 확인하였고(Tables 1 and 2), 병리 학적 특성(Table 3)과 수술 후 병기 및 위험도(Table 4)를 확 인하였다. 
휘틀세포암 환자의 평균 연령은 50.8(36 71)세, 남녀 비는 3:9였다. 주 증상은 경부 종괴인 경우 7예(58.3\%), 영상학적 검 사상 우연히 발견된 경우 4예(33.3\%), 절제 생검을 통해 확인 한 원격 전이(전완부 종괴)의 경우 1 예(8.3\%)였다. 수술 전 세 침흡인검사 결과는 휘틀세포 종양 6예(50\%), 여포상 종양 4예 (33.3\%), 여포상 종양 의심 1예(8.3\%), 휘틀세포 특성의 미확 정 비정형 세포 1 예(8.3\%)였다. 처음부터 갑상선 전 절제술을 시행한 경우는 4예(33.3\%)였고, 그 중 1예(8.3\%)에서는 측경 부 청소술을 같이 시행하였다. 엽 절제술 후 완결 절제술을 시행한 경우는 3예(25\%)였다. 엽 절제술만 시행한 경우는 5예 (41.7\%)였다. 수술 전 세침흡인검사 결과가 대부분 휘틀세포 종양 혹은 여포상 종양이어서 진단적 수술을 시행한 것이기 에 중심 경부 청소술은 시행하지 않았고, 첫 진단 시 측경부 림프절 전이가 있었던 1 예에서만 경부 청소술을 시행하였다. 완결 절제술을 시행한 경우를 포함하여 갑상선 전 절제술이 시행된 환자 7예(58.3\%)에서 모두 방사성 요오드 치료(150 $600 \mathrm{mCi}$ )를 시행하였다(Tables 1 and 2).

수술 후 최종 조직 병리 검사상 휘틀세포암의 크기는 평균 $3.1(0.9 \sim 8) \mathrm{cm}$ 였다. 12예 모두에서 다발성 및 양측성은 확인 되지 않았고, 4예(33.3\%)에서 혈관 침습을 확인할 수 있었다. 병리학적 분류로는 미세 침습형이 8예(66.7\%), 피막 형성형 혈관 침습형이 2예(16.7\%), 광범위 침습형이 2예(16.7\%)였다. 갑상선 주변 구조물을 침습한 경우는 없었다(Table 3).

수술 후 병기(American Joint Committee on Cancer 8th edition)는 Stage I 9예(75.0\%), Stage II 3예(25.0\%)였으며, 미국 갑상선 협회 가이드라인(2015 American Thyroid Association Guideline, 2015 ATA Guideline)에 따른 위험도 분류시 저위험군 9예(75.0\%), 중간위험군 1예(8.3\%), 고위험 군 2예(16.7\%)였다(Table 4).

평균 추적 기간은 82.6(8 233)개월이었고, 추적 기간 동안 국소 재발을 보인 경우는 없었으며, 처음부터 원격 전이를 보 였던 1예에서는 지속적으로 다양한 부위에 원격 전이를 보였
다. 추적 기간 동안 질병으로 인한 사망은 첫 내원 시 원격 전 이를 보였던 1예(8.3\%) 외에는 없었다.

Table 1. Demographics of patients $(n=12)$

\begin{tabular}{|c|c|}
\hline Characteristics & $\mathrm{n}$ \\
\hline \multicolumn{2}{|l|}{ Age (years) } \\
\hline$\geq 55$ & 4 \\
\hline$<55$ & 8 \\
\hline \multicolumn{2}{|l|}{ Sex } \\
\hline Male & 3 \\
\hline Female & 9 \\
\hline \multicolumn{2}{|l|}{ Chief complaints } \\
\hline Neck mass & 7 \\
\hline Abnormal radiologic finding & 4 \\
\hline Forearm mass & 1 \\
\hline \multicolumn{2}{|l|}{ FNA result } \\
\hline Hurthle cell neoplasm & 6 \\
\hline Follicular neoplasm & 4 \\
\hline Suspicious for follicular neoplasm & 1 \\
\hline $\begin{array}{l}\text { Atypia of undetermined significance with Hurthle } \\
\text { cell features }\end{array}$ & 1 \\
\hline \multicolumn{2}{|l|}{ Treatment } \\
\hline \multicolumn{2}{|l|}{ Extent of surgery } \\
\hline Total thyroidectomy & 3 \\
\hline Total thyroidectomy+lateral neck dissection & 1 \\
\hline Lobectomy+completion thyroidectomy & 3 \\
\hline Lobectomy & 5 \\
\hline \multicolumn{2}{|l|}{ Radioactive iodine therapy } \\
\hline High-dose (150-600 mCi) & 7 \\
\hline None & 5 \\
\hline \multicolumn{2}{|l|}{ Recurrence } \\
\hline Yes & 1 \\
\hline No & 11 \\
\hline \multicolumn{2}{|l|}{ Status at last follow-up } \\
\hline DOD & 1 \\
\hline NED & 11 \\
\hline
\end{tabular}

FNA: fine needle aspiration, DOD: died of disease, NED: no evidence of disease
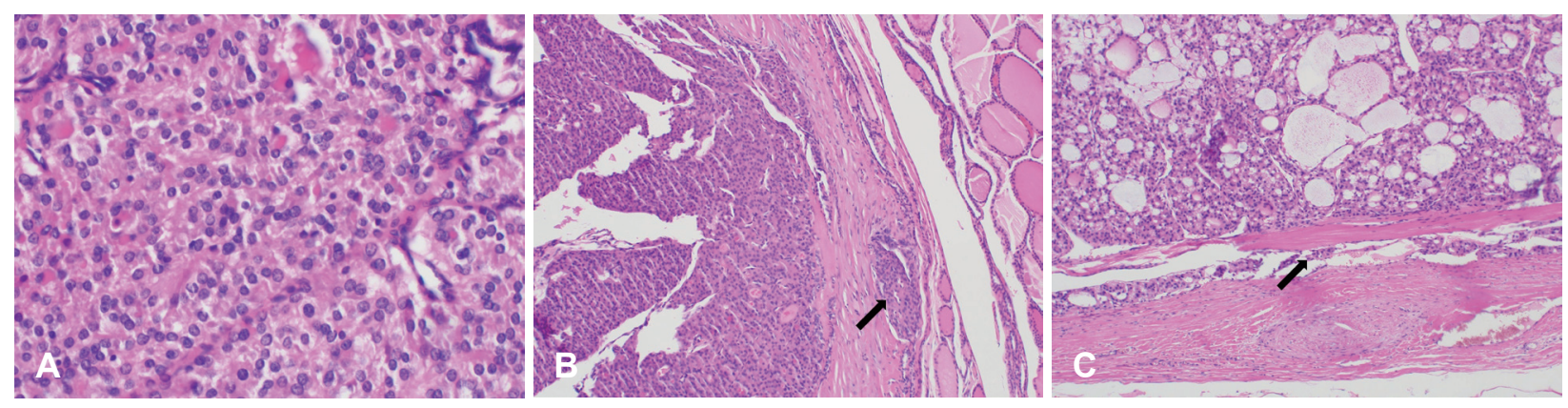

Fig. 1. Microscopic pictures of Hurthle cells and HCC. Hurthle cells. A Hurthle cell is characterized by large, polygonal follicular epithelial cells with distinct borders and eosinophilic, granular cytoplasm (H\&E stain, $\times 400)(A)$. Capsular invasion by tumor cells in HCC (H\&E stain, $\times 100)$. Tumor cells are invading through the fibrous capsule (arrow) (B). Vascular invasion by tumor cells in HCC $(H \& E$ stain, $\times 100)$. A thin vessel contains tumor cells (arrow) with red blood cells (C). HCC: Hurthle cell carcinoma, H\&E stain: hematoxylin and eosin staining. 
12 Cases of Hurthle Cell Carcinoma I Kim JJ, et al.

Table 2. 12 cases of HCC patients $(n=12)$

\begin{tabular}{|c|c|c|c|c|c|c|c|c|c|}
\hline & Age & Sex & $\begin{array}{c}\text { Chief } \\
\text { complaint }\end{array}$ & FNA result & Treatment & RAl therapy & Recurrence & $\begin{array}{l}\text { Follow-up } \\
\text { period }\end{array}$ & $\begin{array}{c}\text { Status at last } \\
\text { follow-up }\end{array}$ \\
\hline Case 1 & 43 & $\mathrm{~F}$ & $\begin{array}{l}\text { Forearm } \\
\text { mass }\end{array}$ & $\begin{array}{l}\text { Follicular } \\
\text { neoplasm }\end{array}$ & $\begin{array}{l}\text { Total thyroidectomy } \\
\text { +lateral neck } \\
\text { dissection }\end{array}$ & + & + & 123 & DOD \\
\hline Case 2 & 67 & M & Neck mass & $\begin{array}{l}\text { Hurthle cell } \\
\text { neoplasm }\end{array}$ & Total thyroidectomy & + & - & 15 & NED \\
\hline Case 3 & 71 & M & Neck mass & $\begin{array}{l}\text { Hurthle cell } \\
\text { neoplasm }\end{array}$ & Total thyroidectomy & + & - & 20 & NED \\
\hline Case 4 & 38 & M & Neck mass & $\begin{array}{l}\text { Hurthle cell } \\
\text { neoplasm }\end{array}$ & Lobectomy & - & - & 56 & NED \\
\hline Case 5 & 45 & $\mathrm{~F}$ & Neck mass & $\begin{array}{l}\text { Hurthle cell } \\
\text { neoplasm }\end{array}$ & $\begin{array}{l}\text { Lobectomy+ } \\
\text { completion } \\
\text { thyroidectomy }\end{array}$ & + & - & 148 & NED \\
\hline Case 6 & 50 & $\mathrm{~F}$ & $\begin{array}{l}\text { Abnormal } \\
\text { radiologic } \\
\text { finding }\end{array}$ & $\begin{array}{l}\text { Hurthle cell } \\
\text { neoplasm }\end{array}$ & $\begin{array}{l}\text { Lobectomy+ } \\
\text { completion } \\
\text { thyroidectomy }\end{array}$ & + & - & 143 & NED \\
\hline Case 7 & 49 & $\mathrm{~F}$ & $\begin{array}{l}\text { Abnormal } \\
\text { radiologic } \\
\text { finding }\end{array}$ & $\begin{array}{l}\text { Follicular } \\
\text { neoplasm }\end{array}$ & Lobectomy & - & - & 122 & NED \\
\hline Case 8 & 56 & $\mathrm{~F}$ & Neck mass & $\begin{array}{l}\text { Follicular } \\
\text { neoplasm }\end{array}$ & Total thyroidectomy & + & - & 102 & NED \\
\hline Case 9 & 56 & $\mathrm{~F}$ & $\begin{array}{l}\text { Abnormal } \\
\text { radiologic } \\
\text { finding }\end{array}$ & $\begin{array}{l}\text { Suspicious for } \\
\text { follicular } \\
\text { neoplasm }\end{array}$ & Lobectomy & - & - & 11 & NED \\
\hline Case 10 & 36 & $\mathrm{~F}$ & Neck mass & $\begin{array}{l}\text { Follicular } \\
\text { neoplasm }\end{array}$ & $\begin{array}{l}\text { Lobectomy+ } \\
\text { completion } \\
\text { thyroidectomy }\end{array}$ & + & - & 10 & NED \\
\hline Case 11 & 49 & $\mathrm{~F}$ & $\begin{array}{l}\text { Abnormal } \\
\text { radiologic } \\
\text { finding }\end{array}$ & $\begin{array}{l}\text { Atypia of } \\
\text { undetermined } \\
\text { significance } \\
\text { with Hurthle } \\
\text { cell features }\end{array}$ & Lobectomy & - & - & 8 & NED \\
\hline Case 12 & 50 & $\mathrm{~F}$ & Neck mass & $\begin{array}{c}\text { Hurthle cell } \\
\text { neoplasm }\end{array}$ & Lobectomy & - & - & 233 & NED \\
\hline
\end{tabular}

HCC: Hurthle cell carcinoma, RAI: radioactive iodine, DOD: died of disease, NED: no evidence of disease

\section{고 찰}

국내의 휘틀세포암에 대한 보고는 매우 드물다. ${ }^{3)}$ 본원에서 는 지난 20년간 6003 명의 분화 갑상선 암 환자를 치료하였으 나, 이 중 휘틀세포암 환자는 12예(0.2\%)로 세계적인 유병률에 비해 현저히 낮은 것을 확인할 수 있었다.

휘틀세포 종양의 세침흡인검사 결과는 대개 여포상 종양, 휘틀세포 변화를 동반한 미확정 비정형 세포, 휘틀세포 종양 의심 등으로 나타나며, 이들의 악성 위험도는 5 30\%로 알려 져 있다. ${ }^{4}$ 본 증례 보고에서의 세침흡인검사 결과도 상기 진단 범주에 포함되었으며 최종 진단이 휘틀세포암으로 확인되었 다. 따라서, 세침흡인검사에서 상기 범주의 진단이 확인되면
진단을 위한 수술적 절제가 필요하다고 할 수 있겠다. ${ }^{5)}$

휘틀세포 종양에서 악성을 시사하는 임상적 인자들에 대한 연구들에서는 공통적으로 고령과 종양의 크기가 큰 경우가 주요 인자로 제시되었다.) 본 증례들 또한 평균 종양의 크기 $3.1 \mathrm{~cm}$, 평균 연령 50.8세로 확인되어서 세침흡인검사에서 휘틀세포 종양이 의심되는 경우 중 비교적 고령에 종양의 크 기가 크다면 암일 가능성이 있으므로 수술적 절제를 포함한 적극적 진단과 치료를 시행해야 한다.

2017 World Health Organization(WHO) 분류에서는 휘 틀세포암이 특유의 생물학적, 임상적 특징을 지녔고 비휘틀 세포 여포암과는 다른 고유한 유전적 특성을 가지고 있어 갑 상선 여포암의 아형이 아닌 독자적인 그룹으로 분류하였다. 
Table 3. Pathologic characteristics $(n=12)$

\begin{tabular}{lc}
\hline \multicolumn{1}{c}{ Characteristics } & $\mathrm{n}(\%)$ \\
\hline Size $(0.9-8 \mathrm{~cm})$ & $4(33.3)$ \\
$\geq 4 \mathrm{~cm}$ & $8(66.7)$ \\
$<4 \mathrm{~cm}$ & \\
Multifocality & $0(0)$ \\
Yes & $12(100)$ \\
No & \\
Bilaterality & $0(0)$ \\
Yes & $12(100)$ \\
No & \\
Angioinvasion & $4(33.3)$ \\
Yes & $8(66.7)$ \\
No & \\
Subclassification & $8(66.7)$ \\
Minimally invasive & $2(16.7)$ \\
Encapsulated angioinvasive (<4 vessels) & $2(16.7)$ \\
Widely invasive & \\
Invasion to adjacent structure & $0(0)$ \\
Yes & $12(100)$ \\
No &
\end{tabular}

Table 4. Classification of HCC patients by AJCC \& ATA guideline $(n=12)$

\begin{tabular}{ll}
\hline \multicolumn{1}{c}{ Category } & $\mathrm{n}(\%)$ \\
\hline AJCC 8th edition prognostic stage group & \\
Stage I & $9(75.0)$ \\
Stage II & $3(25.0)$ \\
2015 ATA guideline risk stratification & \\
Low risk & $9(75.0)$ \\
Intermediate risk & $1(8.3)$ \\
High risk & $2(16.7)$ \\
\hline
\end{tabular}

HCC: Hurthle cell carcinoma, AJCC: American Joint Committee on Cancer, ATA: American Thyroid Association

반면 실제 임상에서 많이 사용되는 국립종합암네트워크 $\left(\mathrm{Na}^{-}\right.$ tional Comprehensive Cancer Network, NCCN) 가이드라 인 최신 개정판(NCCN guidelines version 1. 2020)에서는 휘틀세포암의 치료 방침을 결정하는 데 여전히 $2017 \mathrm{WHO}$ 에 서 개정된 갑상선 여포암의 병리학적 분류를 인용하고 있어 ${ }^{8}$ 향후 병리학적 분류와 임상 치료에 대한 연구와 정리가 필요 할 것으로 생각된다.

휘틀세포암의 수술 방법과 이후 치료에 대해서는 논란이 있다. $2020 \mathrm{NCCN}$ 가이드라인에서는 휘틀세포암의 치료 방 침을 여포암과 비슷하게 제시하고 있다. ${ }^{8}$ 크기가 크거나 전이 가 있는 경우에 1 차 수술로 갑상선 전 절제술을 권유하고, 그 외에는 갑상선 엽 또는 협부 절제술을 시행하고 병리 결과에 따라 추가 수술을 권하고 있다. 광범위 침습형 혹은 4개 이상 의 혈관 침범이 있는 피막 형성형 혈관 침습형 휘틀세포암은 완결 절제술이 권유되며 4개 미만의 혈관 침범이 있는 피막
형성형 혈관 침습형과 미세 침습형 휘틀세포암은 상황에 따 라 완결 절제술 혹은 단순 추적 관찰을 선택할 수 있다. 본 증례에서는 광범위 침습형 2예에서 모두 갑상선 전 절제술을 시행하였으나 그 중 1 예에서 다발성 전신 전이 및 질병으로 인한 사망 등의 불량한 예후를 확인할 수 있었다.

재발 중간위험군, 고위험군 환자들에서는 갑상선 완결 절 제술 후 방사성 요오드 치료를 시행하는 것이 권유된다.9) 본 원에서 갑상선 전 절제술을 시행한 7예의 환자들은 모두 방 사성 요오드 치료를 시행받았으며, 병이 계속 진행되어 사망 한 1 예를 제외하고는 재발을 보이지 않았다.

추적 관찰 시 초기에는 매 6 12개월마다 티로글로불린 및 안티티로글로불린 항체 검사와 경부 초음파 검사를 시행하고, 재발 고위험군에서는 더 잦은 간격으로 검사를 해야 한다. ${ }^{5,10}$ 이 외에도 경우에 따라서 CT, 뼈 스캔 및 fluorodeoxyglucose PET 검사를 통하여 추적 관찰을 시행할 수 있다. ${ }^{5,11}$

예후는 재발률 7 53\%, 10년 생존율 45 80\% 등으로 다른 갑상선 분화암에 비해 좋지 않다고 알려져 왔으나, ${ }^{12}$ 최근 발 표된 자료들에 의하면 휘틀세포암과 갑상선 여포암의 예후에 큰 차이가 없다고 한다. ${ }^{13)}$ 저자들이 경험한 12 예의 휘틀세포 암의 경우에도 재발과 사망이 1예 밖에 없어서 예후가 나쁘 지 않음을 확인할 수 있었다.

휘틀세포암에 대한 국내 보고는 다른 갑상선 암에 비해 매 우 적고 최근 분류가 바뀌어서 혼돈을 주기 때문에 환자의 진단과 치료에 도움을 주고자 문헌 고찰과 함께 12예의 증례 를 보고하는 바이다.

\section{Acknowledgments}

None.

\section{Author Contribution}

Conceptualization: Myung-Chul Lee. Data curation: Jung Jun Kim. Methodology: Ju Yong Kang. Project administration: MyungChul Lee. Supervision: Myung-Chul Lee. Validation: Ik Joon Choi. Writing — original draft: Jung Jun Kim. Writing — review \& editing: Myung-Chul Lee.

\section{ORCID}

Myung-Chul Lee https://orcid.org/0000-0002-2574-4976

\section{REFERENCES}

1) Goffredo P, Roman SA, Sosa JA. Hurthle cell carcinoma: A population-level analysis of 3311 patients. Cancer 2013;119(3):50411.

2) Moon SS, Kang SJ, Kim SY. Hurthle cell tumor of the thyroid gland. Korean J Head Neck Oncol 1992;8(2):106-16.

3) Lee J, Lee SH, Choi SY, Nam KH, Chung WY, Soh EY, et al. Hurthle cell carcinoma of the thyroid gland: Clinicopathologic features and treatment outcome compared with pure follicular thyroid carcinoma. J Korean Surg Soc 2008;74(2):91-7.

4) Cibas ES, Ali SZ; NCI Thyroid FNA State of the Science Conference. 
The bethesda system for reporting thyroid cytopathology. Am J Clin Pathol 2009;132(5):658-65.

5) Haugen BR, Alexander EK, Bible KC, Doherty GM, Mandel SJ, Nikiforov YE, et al. 2015 American Thyroid Association management guidelines for adult patients with thyroid nodules and differentiated thyroid cancer: The American Thyroid Association guidelines task force on thyroid nodules and differentiated thyroid cancer. Thyroid 2016;26(1):1-133.

6) Kim TH, Lim JA, Ahn HY, Lee EK, Min HS, Kim KW, et al. Tumor size and age predict the risk of malignancy in Hürthle cell neoplasm of the thyroid and can therefore guide the extent of initial thyroid surgery. Thyroid 2010;20(11):1229-34.

7) Kakudo K, Bychkov A, Bai Y, Li Y, Liu Z, Jung CK. The new 4th edition World Health Organization classification for thyroid tumors, Asian perspectives. Pathol Int 2018;68(12):641-64.

8) National Comprehensive Cancer Network. Clinical practice guidelines in oncology-thyroid carcinoma. version 1. 2020. [serial online] 2020 June [cited 2020 June 17] Available from: URL: https://www. nccn.org/professionals/physician gls/pdf/thyroid.pdf

9) Stojadinovic A, Hoos A, Ghossein RA, Urist MJ, Leung DH, Spiro RH, et al. Hürthle cell carcinoma: A 60-year experience. Ann Surg Oncol 2002;9(2):197-203.

10) Ahmadi S, Stang M, Jiang XS, Sosa JA. Hürthle cell carcinoma: Current perspectives. Onco Targets Ther 2016;9:6873-84.

11) Pryma DA, Schöder H, Gönen M, Robbins RJ, Larson SM, Yeung HW. Diagnostic accuracy and prognostic value of 18F-FDG PET in Hürthle cell thyroid cancer patients. J Nucl Med 2006;47(8):1260-6.

12) McHenry CR, Phitayakorn R. Follicular adenoma and carcinoma of the thyroid gland. Oncologist 2011;16(5):585-93.

13) Bhattacharyya N. Survival and prognosis in Hürthle cell carcinoma of the thyroid gland. Arch Otolaryngol Head Neck Surg 2003; 129(2):207-10. 